\title{
Le sacrifice humain ches les Aztèques : question de technologie?
}

Dominique Fournier

\section{(2) OpenEdition \\ Journals}

Édition électronique

URL : https://journals.openedition.org/tc/952

DOI : $10.4000 /$ tc. 952

ISSN : 1952-420X

Éditeur

Éditions de l'EHESS

\section{Édition imprimée}

Date de publication : 1 juin 1985

ISSN : 0248-6016

\section{Référence électronique}

Dominique Fournier, "Le sacrifice humain ches les Aztèques : question de technologie ? », Techniques \& Culture [En ligne], 5| 1985, mis en ligne le 25 janvier 2006, consulté le 29 septembre 2022. URL:

http://journals.openedition.org/tc/952 ; DOI : https://doi.org/10.4000/tc.952

Ce document a été généré automatiquement le 29 septembre 2022.

Tous droits réservés 
Le sacrifice humain ches les Aztèques : question de technologie?

Dominique Fournier 